\title{
Formation of National Idea as A Factor of National Security of The State as Part of The State and Administrative Dimension
}

\author{
Inna Gryshova, doctor of Economics, Professor Department of Public Administration and Innovation \\ Management, National University of Life and Environmental Sciences of Ukraine, orcid.org/0000-0001- \\ 6276-7619,2606147@ukr.net \\ Oksana Parkhomenko-Kutsevil, Doctor of Science in Public Administration, Professor, Head of the \\ Department of Public Administration of the Pereyaslav-Khmelnytsky State Pedagogical University named \\ after Hryhoriy Skovoroda, Pereyaslav, Ukraine, ORCID https://orcid.org/0000-0002-0758-346X, \\ pkoi@ukr.net \\ Iryna Sedikova, Doctor of Economics, Professor of the Department of Management and Logistics Odessa \\ National Academy of Food Technologies, irina-sedikova@ukr.net, https // orcid.org / 0000-0001-5684-6927 \\ Volodymyr Oliinyk, Doctor of Science in Public Administration, Professor Department of Public \\ Administration and Innovation Management National University of Life and Environmental Sciences of \\ Ukraine, Oliynyk-v-v@ukr.net, https://orcid.org/0000-0002-4647-2658
}

\begin{abstract}
The article systematizes approaches to the concept of "national idea", defines that the national idea, first, shapes people's sense of being a single nation; second, it is an undeniable unifying constant in society; thirdly, it is acceptable to all communities and populations of the country; fourth, it is a consequence of the historical development of the ethnos and the nation; Fifth, it is based on a system of national values and linked to national culture; sixth, it is a strategic goal that must unite the nation and create the conditions for further positive developments and actions. The authors argue that for the existence and formation of a national idea, the following conditions must be realized: a) there must be an independent Ukrainian state as a form of organization and foundation of vitality of the Ukrainian nation, which is an aggregate of ethnic groups, or, if the state does not exist, it must exist in the minds of the Ukrainian people the will to self-determination, which is realized in one's own national liberation struggle; b) there must be an understanding of the Ukrainian people as a community of ethnicities, a nation separate from other nations, that is, having distinct, specific, purely national cultural features that do not coincide with those of other nations. After all, people who have lost their national traits are a denationalized people. The national idea is the basis for the formation of a national culture that influences not only national identification but also the processes of reforming and modernizing all spheres of society.
\end{abstract}

Keywords: security, national security, basic security principles, national idea.

Received: 09.12.2020 Accepted: 11.01.2021 Published: 07.02.2021

\section{Problem statement}

Ensuring the national security is a matter of forming the national strategy related to the domestic politics of the state and aimed at achieving and maintaining social stability and progressive development of society. The state security issue has always been relevant, and has often been a priority for any society and government authorities at all stages of its formation and development.

The formation of the sense of national identity fundamentally influenced the state structure, and accordingly the attitude of authorities to the "security".

The national security implies not only the security of state authorities, but first of all, the real security and guarantee of the rights of individual citizens, public and political organizations, ethnic and other minorities, etc.

That is why the "national security" category is fundamental in development and functioning of any state. The value system of a given society institutionalized in ideology or in national idea is another of such leading value constructs of the state. Indeed, any value system of a person is always aimed at meeting its diversified own needs that are transformed into personal, group and public interests. In turn, these needs and interests, generated by material and spiritual conditions of human existence, form an appropriate value system and are institutionalized in the form of ideology and/or national idea. The social force of ideological system of society is so great that any person who tries to live contr ary to the 
established value system of the state will either be rejected by society (deprived of citizenship, removed from the state, imprisoned) or be turned into a fringe incapable of a more or less significant social role.

\section{Analysis of scientific publications}

Various aspects of the Ukrainian national idea are explored in the works of such famous Ukrainian scholars as (Gryshova, I.; Kofman, B.; Petrenko, 0.,2019),( Azer Dilanchiev, Gryshova Inna, 2020) , (Dr. Tetiana Tielkiniena, Gryshova Inna, Shabatura Tatyana, 2020) Dragan Ivan.O., Kovalova Olena, Gryshchenko Iryna, Ridei Nataliia, Livinskyi A. I. Assessment Of The Role Of The State As A Leader In The Demographic Development Of Ukraine. 2020) and others.

According to M. Piren, the national idea is intended to consolidate the Ukrainian political nation not as a single over-party ideology and not through state coercion, but as a common platform of all those political, public, and cultural forces that recognize the basic constitutional foundations of our national existence (Dr. Tetiana Tielkiniena, Gryshova Inna, Shabatura T, Nehodenko V, Didur H, Shevchenko A, 2020). One of the key challenges to the integrity and unity of the state, its national security is the lack of national idea that would unite society.

In modern sense, "security" is a rather large concept that is applied to many processes. The distinguished scientist S. Ozhegov interprets security as a "condition in which there is no danger, there is protection against danger" (Monteske Sh.,1995).

Objective of the study involves analysis and role of formation of national idea as part of development of modern states and their influence on formation of national security of the state, as part of their interaction.

\section{Statement of basic materials}

In our opinion, the state security is the internal status and international position of the state, which protects its national interests, existing political system and territorial integrity, as well as removes the real threat of internal destabilization or aggression by other states. In general, the national security of each state includes political, economic, military, environmental, information security and so on.

In our opinion, the concept of "security" as one of the most important characteristics of a targetoriented system should be taken as the primary prerequisite when analyzing the security category. Based on the above, the categories revealing the meaning of concept of national security, such as environmental hazard, disaster, crisis, sources of danger, factors of danger, and finally the very concept of societal security can be introduced into scientific use.

From the XIX to the beginning of the XX century, when a new concept of nation as a historically formed stable community of people, which arose on the basis of shared territory, economic life, language and mental composition manifesting in the shared culture, was formed, the corresponding concepts appeared: "national security", "national interests" and "national idea". In this context, the influence on formation of national interests, development of national ideas and ideologies based on it is an important element in formation of each state. In general, the national interests are a balanced set of interests of individuals, communities, society and state in the economic, domestic political, social, international, information, military, border, environmental and other spheres. They are long-term and define the main goals, strategic and current tasks of the domestic and foreign policy of the state.

The educational activities of members of intellectual communities and professional groups, the representatives of which produce and transfer knowledge and values, are the most important source of forming the positive civic identity. The elite groups in the government and business, mass media and youth are the priority objects of such activities; it is essential to incentify and ensure such activities at the level of primary socialization, which is the higher education institutions. It is not just about getting the knowledge and skills to work with that knowledge and learn new ones. The humanitarian knowledge creates foundations for analysis of changing world and forms its aesthetic perception, but such knowledge becomes a tool of positive social action when it is built based on clear and ground moral principles (Gryshova, I.; Kofman, B.; Petrenko, O. (2019).

The concept of "national idea" is analyzed by scientists in various fields, including: economics, political science, social studies, legal studies, philosophy and public administration. At the same time, there is currently no single systemic concept of "national idea". In addition, the functions of national idea, its role in the life of society and possibility of forming the national culture are imperfectly revealed.

Based on the analysis of scientific literature on the subject, it can be noted that the concept of "national idea" is analyzed on various aspects, including:

- perception of citizens of their optimal national and consolidating behavior for their own benefit and that of the nation (Gryshchenko I. M, 2016); 
- political project of the future of nation, imperative of its consciousness and rank, life-purpose factor of national development (Gryshova, I.; Kyzym, M.; Hubarieva, I.; Khaustova, V.; Livinskyi, A.; Koroshenko, M,.2020);

- certain set of beliefs, national views and understanding, particular spiritual and intellectual potential of nation, man - state-minded person and compatriot (Gryshova, I.; Kyzym, M.; Hubarieva, I.; Khaustova, V.; Livinskyi, A.; Koroshenko, M.,2020);

- system of values that consists in considering the interests of all population groups, all nations (Azer Dilanchiev, Gryshova Inna, Rogach Svetlana, Diachenko Oleksii, Batrakova Tetyana, Shabatura Tatyana, 2020);

- form of state self-awareness of nation, the indicator of how the nation understand itself, its place and role in the world (Azer Dilanchiev, Gryshova Inna, Rogach Svetlana, Diachenko Oleksii, Batrakova Tetyana, Shabatura Tatyana, 2020);

- part of national dream, represents the essence of nation as a certain human community, which is highly concentrated under the influence of national elite, and defines its role in the world process (Gryshchenko I. M, 2016);

- hierarchical system of spiritual values that is objectively developed during ethnogenesis and nation-building of the indigenous population of Dnieper and Transnistria regions and that adequately reflects the real conditions of existence of this population (Gryshchenko I. M, 2016);

- idea that reflects the main national interest and sets the optimum direction of the country in the present and in the future, making it a rather complex synthesis entity, which, however, can exist in simpler forms - ethnic, political, cultural, etc. But in any case it is a project of social development, an attempt not only to preserve all the useful acquired things, but also to make the society better, more perfect than it is, to modernize it (Trachuk V., 2007);

- value category, phenomenon of spiritual culture that should not be restricted only to its political component. Therefore, it is appropriate to state that the Ukrainian national idea should organically combine the heritage of national spiritual culture and elements of universal political tradition. The national idea as a matrix of state formation reflects the real history of the Ukrainian nation, develops alongside with its formation, but at a higher level of its existence it transforms into the Ukrainian state idea reflecting the interests and feelings of all nations that make up the Ukrainian political nation today (Levchenko N. V., 2009).

The main feature of the national idea is that it can change and transform under the influence of time and circumstances. The search for a "new" national idea as a symbol of development, or through the attempt to destroy the stereotyped images of a certain nation, is a particular symbol of development, which does not deny the idea of stability of national mindset, way of thinking, but only emphasizes that its individual features and peculiarities can be shown only under the pressure of circumstances, or at the "right" time for their full disclosure (Dragan Ivan.O., Kovalova Olena, Gryshchenko Iryna, Ridei Nataliia, Livinskyi A. I.,2020).

Within the context of development of Ukraine as a European state based on democratic principles, return to the old ideological dogmas is impossible - a new integrating state idea is needed, which should be based on democracy, citizenship and patriotism. This idea should unite all citizens of Ukraine into the Ukrainian nation, define the image, motives and affairs of the Ukrainian nation for the whole world, expressing what the Ukrainian people want to achieve in the foreseeable future. The state (national) idea of the Ukrainian people should be clear to the whole world, and, first of all, it should be understood by all compatriots living in Ukraine and abroad, and with their help it should influence the formation and development of national ideas of countries in which they reside and the citizens of which they are. The state idea of the Ukrainian people should serve as a catalyst for spiritual, moral and intellectual unity of the Ukrainian people with the peoples of the EU (Vitiuk D. L., 2018).

The conducted analysis makes it possible to identify the main characteristics of national idea, which include the following:

- national idea creates in people the feeling of a single nation;

- national idea is an indisputable unifying constant in society;

- national idea is accepted by all communities and population of the country;

- national idea is a consequence of historical development of ethnos and nation;

- national idea is based on the system of national values and is connected with national culture;

- national idea is a strategic goal that should unite the nation and create the conditions for further positive changes and actions.

Thus, it can be stated that the following conditions should be implemented for existence and formation of national idea: 
a) there should be an independent Ukrainian state as a form of organization and foundation for vitality of the Ukrainian nation, which is a set of ethnic groups, or, if there is no state, the will of selfdetermination should exist in the mind of the Ukrainian people, which is realized in its own national liberation movements;

b) the Ukrainian people should understand themselves as a community of ethnic groups, nation separate from other nations, that is, the nation having separate, specific, exclusively national cultural features that do not coincide with those of other nations. After all, people who lost their national features are denationalized people (Morar M. V., 2018).

The national idea is the basis for formation of national culture influencing not only the national identification but also the processes of reforming and modernizing all spheres of society.

The national idea should be considered as the idea of nation as a community with the following characteristics:

1) multi-ethnic, consolidated by the institute of citizenship, belonging to Ukraine as a common national;

2) aware of its political purpose - building an independent, economically strong and social, democratic and rule-of-law state;

3) united by shared historical destiny, language, cultural traditions, tolerance of the indigenous, Ukrainian ethnic group to numerous ethnic groups (Prylipko, S., Shevchenko, N., Hryshchenko, 0., 2016).

Based on the analysis of scientific literature we can distinguish the following important features of national idea: first, high level of sense of national identity, morality, legal and civic culture; second, material and spiritual well-being of the population; third, adequate level of support of development of economy, education, science and cultural industries, which will increase the competitiveness of the country.

The concept of national idea should be moved from the philosophical category to the practical category. It should be based not on utopian images, symbols and vivid slogans, but rather become the foundation of a progressive society and the formation of a new paradigm for its development and reform. This is particularly the case with economic and social well-being of citizens of Ukraine (Vadym K., 2011; Prylipko, S., Shevchenko, N., Hryshchenko, 0, 2016; Dragan Ivan.O., Kovalova Olena, Gryshchenko Iryna, Ridei Nataliia, Livinskyi A. I.,2020).

Therefore, one of the aspects of national idea is aiming to reduce the civilizational differences, which will contribute to the formation of political nation. For this purpose, it is necessary to decline imposing certain values specific only to the West or the East, to study and highlight both the values basic to national policies and values common to all ethnic groups, and to stop the speculation on issues dividing the society.

Among these unifying values are the religious and moral values that will be the basis of the spiritual state formation of Ukraine. In this context, Ukraine may become the second Constantinople. "The spiritual state formation of Ukraine is a transition to domination of spiritual, civil and political values, interests of the individual and society, principles of moral, open and responsible policy, high professionalism and dedication, all that can be called the service to people and Motherland. The spiritual renewal as a state ideology, as a national idea in practice should mean consistent, reasonable and open policy, honest, stable and transparent rules in business, total freedom of speech and guaranteed judicial protection of constitutional rights of person and citizen, social justice and protection of the individual, all necessary conditions for self-development and self-realization of a person" ( Gryshova, I.; Kofman, B.; Petrenko, 0.,2019).

Today, the problems of reforming modern Ukrainian society came to the fore, and all systems of society life need to be updated. At the same time, the current reforms are carried out slowly, they are low efficient and have no positive consequences. This is due not only to the professional personnel carrying out the reforms, but also to the corruption that prevents modern society from developing, forming the effective system of public administration.

That is, based on the above the components of national idea are: society;

- comprehensive policy pursued by the administrative government machine in all spheres of

- respect for the national interests of society as a whole;

- laws, rules and regulations governing the social and economic relations;

- geopolitics, i.e. international relations;

- problems of national defense capability of the state;

- cultural and spiritual values of society.

Thus, there is a relation between the concepts of "national security" and "national ideology". In this sense, the national security reflects the national interests that are the object of national security, 
therefore, national security contributes to preservation of ideological foundations in the state. The national idea as a factor of national security should be expressed in a strategic goal, which will direct the action of the citizens of Ukraine to formation of civil consciousness, responsibility for their actions and inaction (Fig.1).

Based on the above, we can claim that national security is aimed at ensuring the sovereignty of the state, ensuring maximum protection of the state from external and internal destabilizing factors, creating external and internal conditions for effective self-dependence of the state and its entry to a competitive economic level on equal basis with the leading countries.

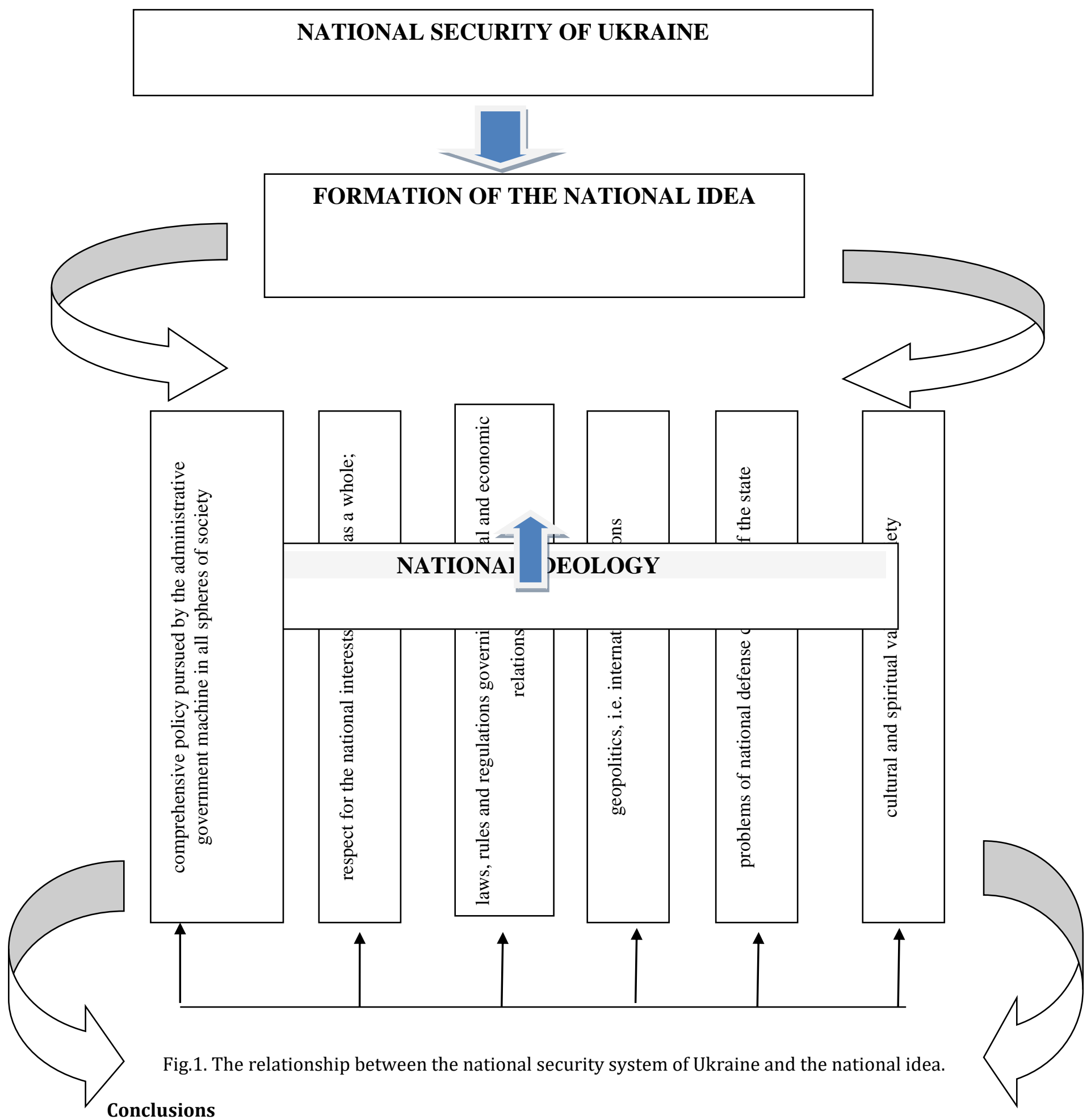

\section{Conclusions}

The article systematizes approaches to the concept of "national idea", defines that national idea, first, creates in people the feeling of a single nation; second, is an indisputable unifying constant in society; 
third, is accepted by all communities and population of the country; fourth, is a consequence of historical development of ethnos and nation; fifth, is based on the system of national values and is connected with national culture; sixth, is a strategic goal that should unite the nation and create the conditions for further positive changes and actions.

\section{References}

Bezklubenko S.D. (2007). "National idea in the context of "universal" values». V Cultural readings of Vladimir Podkopayev's memory "The cultural discourse of the modern world: from the national idea to the globalization civilization": materialy vseukr. nauk.-prakt. konf., 2007, 1-2 cherv., m. Kyiv. K.. P. 13-19.

Vadym K. (2011). "The unity of the country and the protection of human rights are the main components of Ukraine's national idea». URL: http://blogs.pravda.com.ua/authors/kolesnichenko/4ece5ff698860/view_print.

Vitiuk D. L. (2018) «The single state (national) idea as the basis of the unity of Ukraine». Mizhnarodnyi yurydychnyi visnyk: aktualni problemy suchasnosti (teoriia ta praktyka). Vyp. 1-2. P. 9-15. URL: http://nbuv.gov.ua/UJRN/muvnudp_2018_1-2_7

Gryshova, I.; Kofman, B.; Petrenko, O. (2019). Migration cultures and their outcomes for national security, Journal of Security and Sustainability 530.https://doi.org/10.9770/jssi.2019.8.3(18)2q

Hryniv 0. (2001) «The Ukrainian national idea as a problem of science». Etnichna istoriia narodiv Yevropy : zb. nauk. pr. Vyp. 9. P. 4-8.

Levchenko N. V. (2009) «National idea as a factor of state formation in Ukraine». Teoriia ta praktyka derzh. upravlinnia. Vyp. 2. P. 66-75. Monteske Sh. (1995) «Selected Works». M., P. 258, 257, 317.

Morar M. V. (2018) «National idea as a factor of consolidation of the Ukrainian society». Vyp. 131. P. 391395. URL: http://nbuv.gov.ua/UJRN/gileya_2018_131_104

«Political Science Encyclopedic Dictionary» (2004) / Compiled by V.P. Gorbatenko; Edited Yu.S. Shemushenko., V.D. Babkina, V.P. Gorbatenko. 2-he vyd., dop. i pererob. K. : Dovira, 740 p.

«Political Science Dictionary» (2005) / Yu.S. Shemshuchenko (ed.), VP Gorbatenko (ed.). K.: Znannia, 2005. 735 p.

The Ukrainian Political Nation: Genesis, State, Perspectives» (2004) / V.S. Krysachenko, M.T. Stepyko, O.S. Vlasyuk, et al. K. : NISD, 2004. 648 p.

Fartushnyi A. (1999) «National idea as a dynamic system of spiritual values. The Ukrainian National Idea: Realities and Prospects for Development». Lviv : In-t narodoznavstva NAN Ukrainy. Vyp. 1. P. 12-37.

Gryshova, I.; Kyzym, M.; Hubarieva, I.; Khaustova, V.; Livinskyi, A.; Koroshenko, M. Assessment of the EU and Ukraine Economic Security and Its Influence on Their Sustainable Economic Development. Sustainability 2020, 12, 7692

Dr. Tetiana Tielkiniena, Gryshova Inna, Shabatura Tatyana, Nehodenko Viktoriia, Didur Hanna, Shevchenko Alisa. LOBBY LEGALIZATION - LEGAL INSTRUMENT FOR ENSURING STATE SUBSIDIES TO LEADERS OF AGRICULTURAL PRODUCERS. JCR. 2020; 7(4): 1679-1683. doi:10.31838/jcr.07.04.274

Azer Dilanchiev, Gryshova Inna, Rogach Svetlana, Diachenko Oleksii, Batrakova Tetyana, Shabatura Tatyana. REMITTANCE LEVELS AND ENTREPRENEURIAL ACTIVITY IN POSTSOVIET COUNTRIES . JCR. 2020; 7(4): 1655-1663. doi:10.31838/jcr.07.04.271

Gryshchenko I. M. The impact of personal needs on the formation of leadership. Scientific Bulletin of National Mining University (SciVerse Scopus), 2016, vol. 4, pp. 154-160.

Prylipko, S., Shevchenko, N., Hryshchenko, O. Efficiency of small farms functioning in Ukraine. Economic Annals-XXI. 2016. Vol. 158, Issue 3-4(2). P. 17-21 